\title{
Over-expression of mammaglobin-B in canine mammary tumors
}

\author{
Mamta Pandey ${ }^{1 \dagger}$, B. V. Sunil Kumar ${ }^{1 *}$, Kuldip Gupta ${ }^{2}$, Ram Saran Sethi ${ }^{1}$, Ashwani Kumar ${ }^{3}$ and Ramneek Verma ${ }^{1}$
}

\begin{abstract}
Background: Mammaglobin, a member of secretoglobin family has been recognized as a breast cancer associated protein. Though the exact function of the protein is not fully known, its expression has been reported to be upregulated in human breast cancer.We focused on studying the expression of mammaglobin-B gene and protein in canine mammary tumor (CMT) tissue. Expression of mammaglobin-B mRNA and protein were assessed by quantitative real-time polymerase chain reaction (qRT-PCR) and immunohistochemistry (IHC), respectively.

Results: High levels of mammaglobin-B mRNA expression (6.663 \pm 0.841 times) was observed in CMT as compared to age and breed matched healthy controls. Further, expression of mammaglobin-B protein was detected in paraffin-embedded mammary tumor tissues from the same subjects by IHC. Mammaglobin-B protein was overexpressed only in $6.67 \%$ of healthy mammary glands while, a high level of its expression was scored in $76.7 \%$ of the CMT subjects. Moreover, no significant differences in terms of $\mathrm{HC}$ score and QRT-PCR score with respect to CMT histotypes or tumor grades were observed, indicating that mammaglobin-B over-expression occurred irrespective of CMT types or grades.

Conclusion: Overall, significantly increased expression of mammaglobin-B protein was found in CMTs with respect to healthy mammary glands, which positively correlates to its transcript. These findings suggest that overexpression of mammaglobin- $\mathrm{B}$ is associated with tumors of canine mammary glands.
\end{abstract}

Keywords: Canine, Expression, Immunohistochemistry, Mammaglobin-B, Mammary tumor, qRT-PCR

\section{Background}

Mammary tumors are the second most common tumor type, surmounted by skin tumors in dogs primarily affecting unspayed bitches [1]. Early diagnosis of the disease is a challenging task in animals especially in countries like India where periodic visit of dog owners to a veterinarian is not a regular practice. Sometimes, the size of tumor might be very small and located deep within the body making early diagnosis a difficult task. Moreover, the signs and symptoms like pain, weight loss, weakness, etc. are not tumor specific. Few subjects may not at all show any signs and symptoms until the cancer has reached its advanced stages. Hence, it is diagnosed at a late end point of carcinogenesis. Further, in later stages there are more chances of tumor metastasis, leaving the treatment module ineffective [1]. A higher incidence of mammary tumors

\footnotetext{
* Correspondence: drbvskumar@gmail.com

${ }^{+}$Mamta Pandey and B. V. Sunil Kumar contributed equally to this work.

${ }^{1}$ School of Animal Biotechnology, Guru Angad Dev Veterinary and Animal

Sciences University, Ludhiana, Punjab 141004, India

Full list of author information is available at the end of the article
}

in canines and the need to diagnose them at an early stage are motivating factors to aim development of better screening and diagnostic methodologies. In this pursuit, discovery of novel biomarkers, which are sensitive and specific enough to diagnose this malady, are essentially required.

Mammaglobin- $B$ is one of the 23 members of the secretoglobin superfamily, a group of small, secretive, seldom glycosylated proteins [2]. Gene encoding mammaglobin-B was identified in the studies of differentially expressed cDNAs from carcinoma cell lines of human breast cancer [3]. Unlike other members, its expression is highly specific to the mammary gland and is expressed at a low level in normal and healthy mammary tissue [4]. It is detected in breast tissue as a complex with lipophilin B [5] and its expression is reported to increase with breast carcinogenesis [4]. Increased expressions of mammaglobin have been observed in breast cancer derived cell lines [6] and human breast cancer tissues [3, 7-12]. Although its role in cancer immunopathology is not clearly defined, but it is thought to be involved in signalling, immune response, chemotaxis 
and are possibly carriers of steroid hormones [13]. It is also considered as a promising molecular marker for disseminating and circulating breast cancer cells [4]. So far, the mammaglobin expression studies are well reported for human breast cancers but no such reports are documented for mammary tumors in canines. In our previous study we reported detection of this protein for the first time in the serum of canines with mammary carcinomas [14].

Quantitative real time-PCR (qRT-PCR) and immunohistochemical diagnosis of canine mammary tumors (CMTs) targeting tumor specific markers are the most widely used methods to score the expression status of markers. This will lead to introduction of new biomarkers, which may aid in treatment and prognosis of the tumorous condition. In addition, diagnosis could be done at an early stage that may increase the survival period of afflicted dogs. In this context, the purpose of this study is to quantify mammaglobin-B transcript by qRT-PCR and protein by immunohistochemical analysis in CMTs. In this study, for the first time we presented the expression of mammaglobin-B at mRNA and protein levels and their correlation with various histotypes of CMTs and their histological grades of malignancy.

\section{Methods}

\section{Animals and tissue samples}

Biopsies from tumor free apparently healthy mammary glands $(n=30)$ and mammary tumor tissues $(n=30)$ were collected from age and breed matched female dogs brought to Department of Veterinary Surgery and Radiology of Guru Angad Dev Veterinary and Animal Sciences University, India. After the removal of tumors and post-operative care, the animals were discharged from the clinics and allowed to go with their owners. All the animals under investigation were in the age group of 5-12 years (Median: 7.25). The animals had neither received any treatment even in the form of any non-steroidal anti-inflammatory drug nor chemotherapy prior to surgery. Only unsprayed female canine subjects were considered for the present study. Healthy canine mammary gland biopsies were also taken from the subjects that were brought to the clinics. The samples were stored in RNAlater (Sigma, USA) as well as $10 \%$ neutral buffered formalin (NBF) for RNA isolation and immunohistochemistry (IHC), respectively. Permission for collection of the samples from the canines used in this experiment was approved by the institution's animal ethics committee vide edorsement no. VMC/12/3901-35.

\section{RNA isolation and complementary DNA (CDNA) synthesis}

Total RNA was extracted from the tissue samples using TRIzol (Thermo Scientific, USA) [15]. $1 \mu \mathrm{g}$ of isolated RNA from each sample was reverse transcribed to cDNA using Oligo dT primers and RevertAid premium first strand cDNA synthesis kit (Thermo Scientific, USA) following the manufacturer's instructions.

\section{Quantitative real-time PCR (qRT-PCR)}

cDNA isolated from healthy and tumorous mammary tissues were used for qRT-PCR. Using the available sequence of canine mammaglobin-B (AB971219.1) from NCBI, gene specific oligonucleotide primers (GCAATGTTTTCTCC AGCAGTCG and GTCCCTGTCCACTGGTTTGAAA) were designed for qRT-PCR. Beta actin ( $\beta$-actin)gene with primer sequences: CCGCGAGAAGATGACCCAGA and GTGAGGATCTTCATGAGGTAGTCGG [16] and RPS19 gene with primer sequences: CCTTCCTCA AAAAGTCTGGG and GTTCTCATCGTAGGGAGCA AG [17] were used as valid internal controls. RPS19 gene encodes for ribosomal protein S19 of the 40S ribosomal subunit. This gene had been used as valid internal control in earlier cancer studies [18]. Non template control was kept to check for non-specific amplification. All the primers were used at $0.2 \mu \mathrm{M}$ final concentration. Power SYBR Green QPCR master mix (Applied Biosystems) was used for amplification of the genes. Samples were run in triplicates. The dissociation curves were generated between 60 and $95{ }^{\circ} \mathrm{C}$ to assess specificity of amplicons. The threshold cycle $(\mathrm{Ct})$ values obtained for each test and internal control genes ( $\beta$-actin and RPS19) after 40 cycles of amplification were used to measure the relative expression of mammaglobin-B gene in tumor and healthy tissues as per Abasht et al. (2009) [19]. Statistical analyses were done as per Livak and Schmittgen (2001) [20] and comparisons were made by student's $t$ test using SAS version 9.3. The percent PCR amplification efficiencies (E) for each of the assay was calculated as $\mathrm{E}=\left(10^{-1 / \text { slope }}-1\right) \times 100$ [21]

\section{Histopathology}

About $5 \mu \mathrm{m}$ sections of paraffin wax embedded tumor tissue samples were stained with haematoxylin and eosin (HE) for microscopic evaluation. All the tumors were classified according to World Health Organization (WHO) criteria of tumor classification [22] with slight modifications as per Goldschmidt et al. (2011) [23]. Thirty CMTs were classified into 13 complex carcinomas (43.3\%), 11 simple carcinomas (36.7\%), 4 carcinosarcomas (13.3\%) and 2 fibrosarcomas (6.7\%). The histological grades of malignancy of the CMTs were also assessed according to Goldschmidt et al. (2011) [23]. About 33.33\% tumors $(n=10)$ were found to be of grade I (well differentiated), $60 \%$ $(n=18)$ of grade II (moderately differentiated) and $6.67 \%$ $(n=2)$ of grade III (poorly differentiated).

\section{Immunohistochemistry}

Previously we have cloned and heterologously expressed canine mammaglobin-B gene in E. coli as $12 \mathrm{kDa}$ recombinant fusion protein and raised hyperimmune sera 
against the expressed protein in rabbits [14]. IgG purified from the hyperimmune sera [14] was used as primary antibody for IHC. Total proteins were extracted from the mammary tumor tissues [24] and Western blot [25] was carried out using the purified IgG to assess specificity of the raised antibodies.

The IHC technique was employed as standardized earlier [26] with slight modifications. Briefly, $3 \mu \mathrm{m}$-thick sections were cut from the tissue embedded blocks and fixed to poly- L-lysine-coated slides. The slides were de-paraffinized and rehydrated in graded alcohols. A modification of heat-induced epitope retrieval was done by boiling the sections first in citrate buffer at $70 \mathrm{~W}$ for 15 min followed by a brief wash with deionized water and boiling the sections in tris-ethylene diamine tetra acetic acid (EDTA) buffer at $70 \mathrm{~W}$ for $10 \mathrm{~min}$ in a microwave oven. Sections were then allowed to cool down to room temperature in tris-EDTA buffer. Endogenous peroxidase was quenched by incubating sections in $3 \%$ hydrogen peroxide solution in methanol for $20 \mathrm{~min}$. To reduce non-specific binding, slides were incubated with power block (Vector Laboratories, USA) for $15 \mathrm{~min}$ at room temperature. Primary antibody was used at 1:200 dilution, and slides were incubated overnight in a humidified chamber at $4{ }^{\circ} \mathrm{C}$. IgG purified from pre-immune sera was used as negative control to confirm the specificity of immunostaining [27]. Horseradish peroxidase (HRPO) conjugated goat anti-rabbit IgG (Santa-Cruz Biotechnology, USA) was used as secondary antibody at a dilution of 1:2500. A freshly prepared 3, 3'-diaminobenzidine (DAB) solution (DAB Peroxidase Substrate Kit-Vector Laboratories, USA) was used to visualise the colored reaction. Finally, the slides were immersed in distilled water, counterstained with Gill's haematoxylin (Sigma GH5-2-16) stain and permanently mounted.

\section{Semiquantitative scoring of mammaglobin positive cells}

The immunohistochemical analysis of positive cases was done by semiquantitative method in which both the intensity of the brown color developed and the percentage of cells showing positive staining were taken into consideration. The scoring was done by pathologists blinded to patient's history [28]. To calculate the staining index (SI or H-score), the score allotted for the percentage of immuno-positive cells was multiplied by the score allotted for the staining intensity.The value calculated for SI score was used to define higher $(\mathrm{SI} \geq 6)$ or lower $(\mathrm{SI}<6)$ expression of the mammaglobin- $\mathrm{B}$ protein at tissue level $[28,29]$. The percentage of immuno-positive cells was obtained from 20 random fields per case per section using a 40X objective lens. The percentage of positive cells, was quantified by arbitrarily assigning scores as follows: $0-25 \%$ positive cells: $1 ; 26-50 \%$ positive cells: 2 ; 51-75\% positive cells: $3 ; 76-100 \%$ positive cells: 4 .
Staining intensity i.e. severity of brown color developed after staining was scored as 0 in case of no staining, 1 for weak staining, 2 for moderate staining and 3 for strong staining.

\section{Statistical analysis}

All statistical analyses were performed using statistical analysis software (SAS ver. 9.3). The association between $\mathrm{H}$-score and $2^{-\triangle C T}$ (qRT-PCR score) was determined using the Pearson correlation coefficient (r). Spearman's rank correlation between the scores was also calculated to assess how well the relationship between the two variables could be described using a monotonic function. Scatter-plots were generated for graphical illustrations of correlation between H- and qRT-PCR-scores. Regression analysis was also performed for exploring the relationship between H-score and qRT-PCR score. The Kruscal Wallis test was used to determine statistical association of $\mathrm{H}$ scores, qRT-PCR score and grades of tumor with the tumor histotypes.

\section{Results}

\section{Mammaglobin mRNA expression}

Amplification efficiencies of mammaglobin-B, $\beta$-actin, and RPS19 genes were found to be 91.6, 93.8, and 99.4\% respectively, indicating appropriate exponential efficiencies for these reactions. Mammaglobin- $\mathrm{B}$ gene was found to be $6.663 \pm 0.841$ times significantly up-regulated $(P \leq 0.05)$ in CMT as compared to the healthy glands (Fig.1).

\section{Mammaglobin protein expression}

IgG purified from the hyperimmune serum reacted specifically with mammaglobin-B on nitrocellulose membrane out of the total proteins extracted from tumor tissue (Fig.2), confirming specificity of the purified IgG against canine mammaglobin-B.

A low mammaglobin-B protein expression was observed in healthy mammary tissue (Fig. 3). Only $6.67 \%$ of healthy mammary tissue sections showed SI $\geq 6$. However, mammaglobin-B specific immunostaining was observed in all the CMT sections with a clear variation in the percentage of immuno-positive cells. A strong positive immunoreactivity to the protein was detected in most of the CMT tissues (Figs. 4, 5, 6, 7) indicating higher expression of mammaglobin-B protein in tumor cells. Thus, a higher level of immunostaining was seen in 23 out of 30 specimens (76.7\%). All the complex carcinomas showed a higher level of mammaglobin-B expression (i.e. SI score $\geq 6$ ), whereas, for simple carcinomas higher protein expression was observed in $63.63 \%$ cases. For carcinosarcoma and fibrosarcoma, $50 \%$ of the cases had higher expression of mammaglobin-B protein with SI score $\geq 6$. Moreover, $70 \%$ of grade I, $83.33 \%$ of grade II and $50 \%$ of grade 


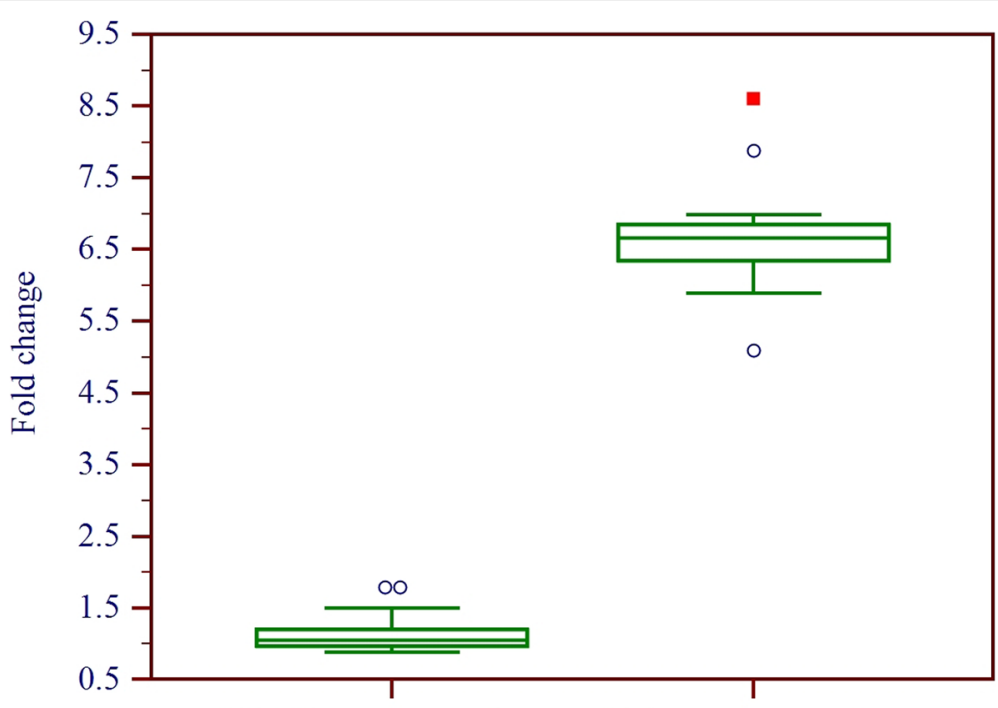

Healthy mammary tissue Canine mammary tumor

Fig. 1 Box and whisker's plot showing fold change in mammaglobin-B gene expression in healthy and tumorous mammary tissue

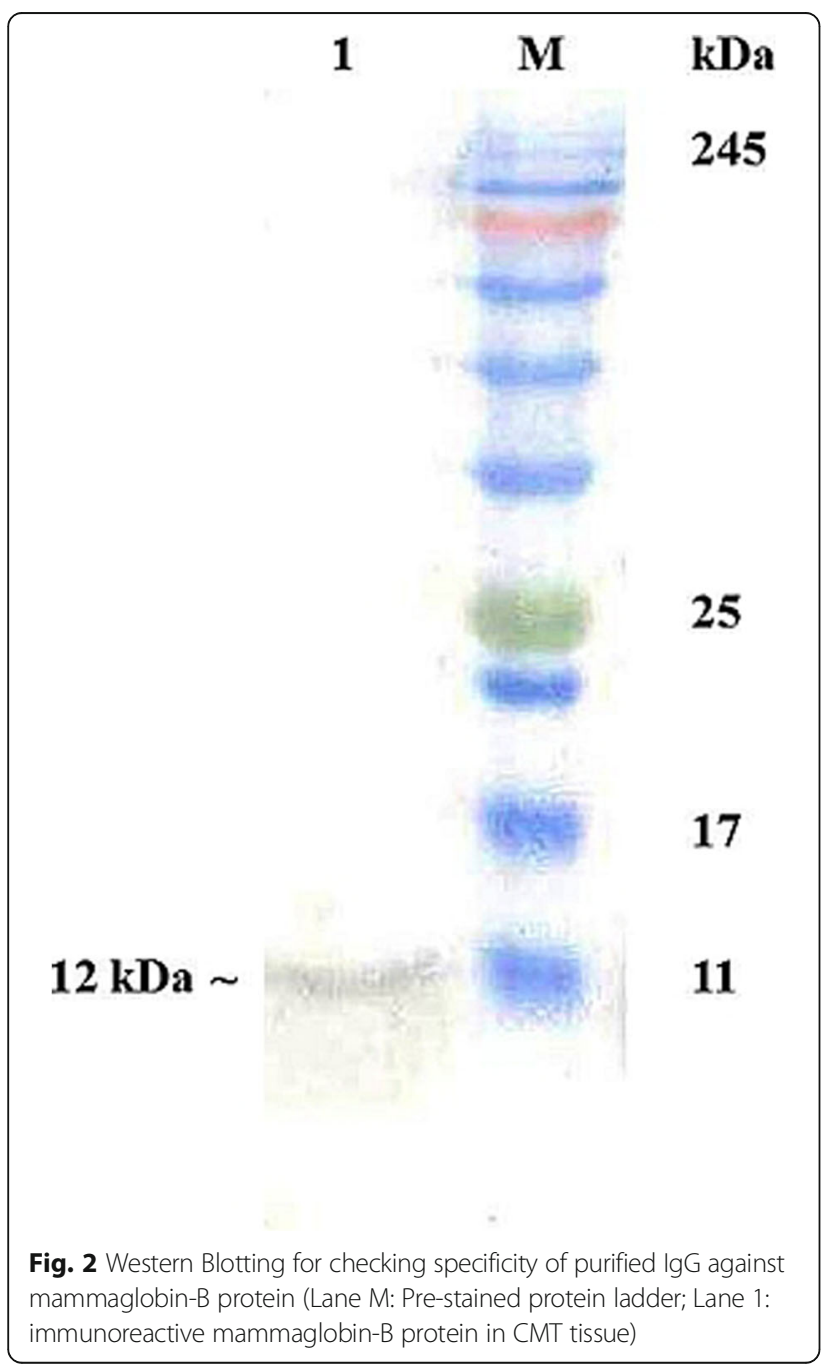

III CMT cases had higher mammaglobin-B protein expression with SI score $\geq 6$.

Correlation between mammaglobin-B mRNA and protein expression in different histotypes and grades of CMT Scatter plot, demonstrated a positive and significantly high correlation $(P<0.0001)$ between mammaglobin- $\mathrm{B}$ transcript and protein expression (Pearson Correlation coefficient $=0.8394$ ) (Fig. 8). Spearman's rank correlation between $\mathrm{H}$-score and $2^{-\triangle \mathrm{CT}}$ was found to be 0.762 $(P<0.0001)$ indicating that the rankings for mammaglobin-B transcript and protein expression among different specimens were highly similar. A regression equation $(\mathrm{H}=0.357+48.335 \mathrm{X}$; where $\mathrm{H}$ represents

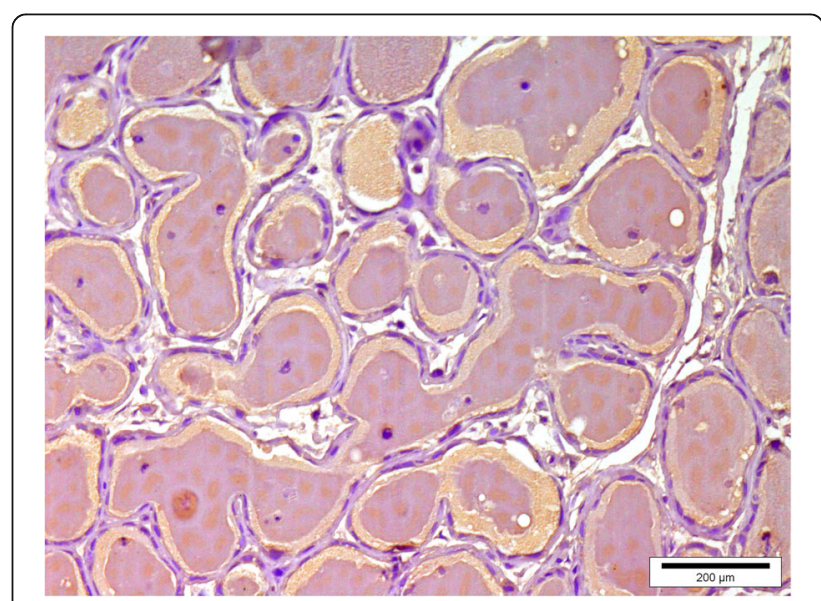

Fig. 3 Immunohistochemistry of healthy canine mammary grand depicting low levels of mammaglobin-B immunopositive cells. Bar $=200 \mu \mathrm{m}$ 


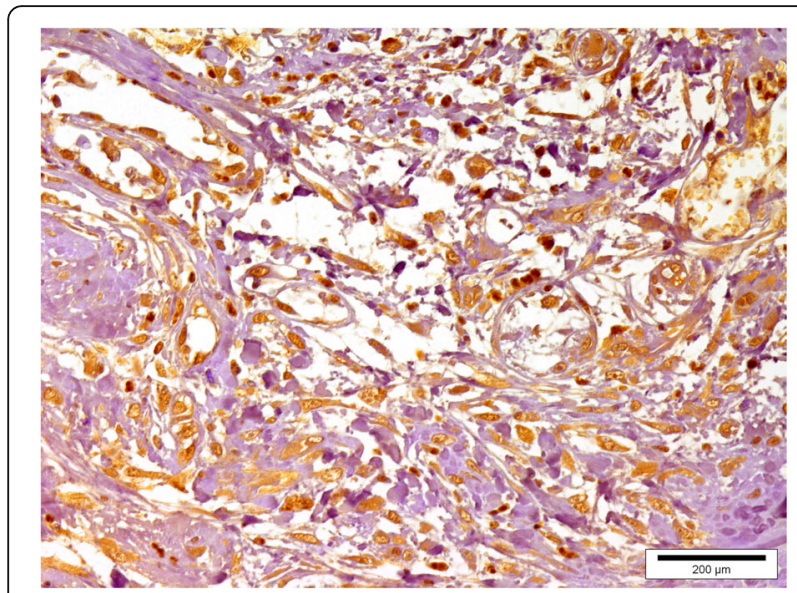

Fig. 4 Immunohistochemistry of canine mammary tumor (Complex carcinoma showing mammaglobin-B immunopositive cells). Bar = $200 \mu \mathrm{m}$

$\mathrm{H}$ - score and X represents the qRT-PCR score) was obtained which could predict $\mathrm{H}$-score from the qRT-PCR score with $\mathrm{r}^{2}$ value of $70.47 \%$. The relationship between both the scores was found to be linear, suggesting that mammaglobin- $\mathrm{B}$ transcript appropriately predicts the protein expression in CMT. However, the Kruscal Wallis test revealed no significant differences in terms of $\mathrm{H}$ score and qRT-PCR score with respect to CMT histotypes or tumor grades, indicating that mammaglobin- $\mathrm{B}$ over-expression occured irrespective of the histological parameters studied.

\section{Discussion}

Dogs, primarily unspayed bitches are most frequently affected by mammary neoplasia which are usually diagnosed at a late end point of carcinogenesis making them irresponsive to treatment [1]. One of the best ways to increase efficacy of CMT treatment is by diagnosing them in their early stages. This can be achieved only by

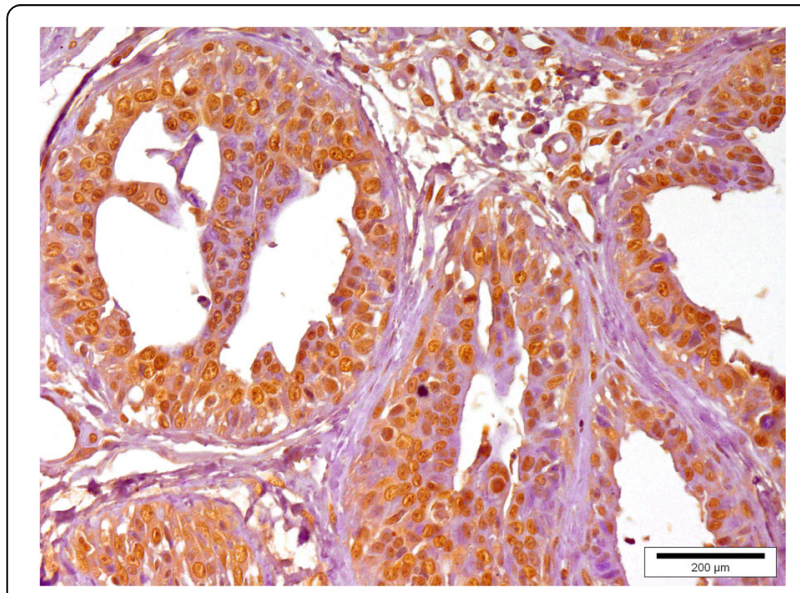

Fig. 5 Immunohistochemistry of canine mammary tumor (Simple carcinoma showing mammaglobin-B immunopositive cells). Bar $=200 \mu m$

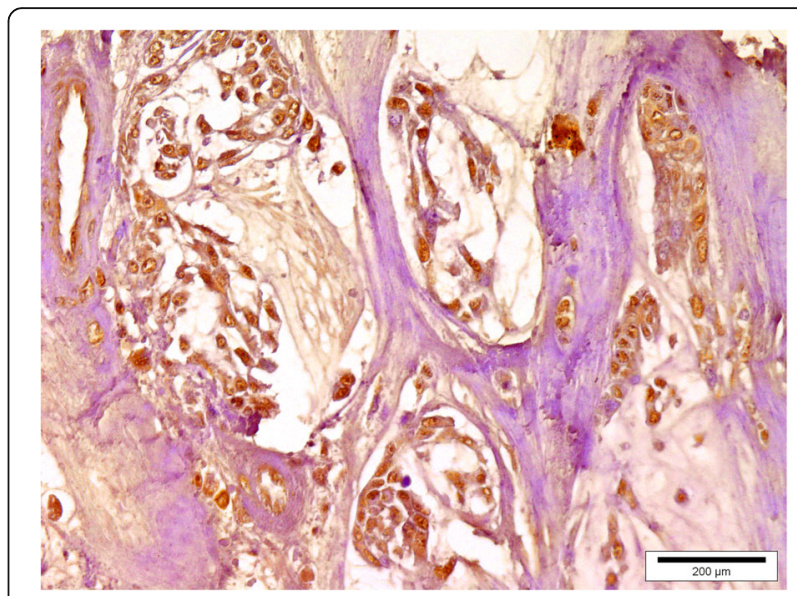

Fig. 6 Immunohistochemistry of canine mammary tumor (Carcinosarcoma showing mammaglobin-B immunopositive cells). Bar $=200 \mu \mathrm{m}$

employing those biomarkers which are capable enough to distinguish the tumorous glands from the healthy ones. The present panel of canine mammary tumor biomarkers are mostly non-specific that fail to aid early tumor detection. In the past, we have put considerable efforts in search of biomarkers for the diagnosis and prognosis of CMT $[18,30]$. So, in the line of thought to explore out a best suited panel of biomarkers for diagnosing mammary tumors we studied the mammaglobin- $B$ gene, because a single biomarker is never $100 \%$ efficient to give a perfect conclusion. Specificity and sensitivity of mammaglobin to detect human breast cancer makes it a promising biomarker [31]. Till now, to our best knowledge there is only one report from our laboratory in which we had investigated the potential of mammaglobin-B protein as a serum biomarker of canine mammary carcinomas [14]. However

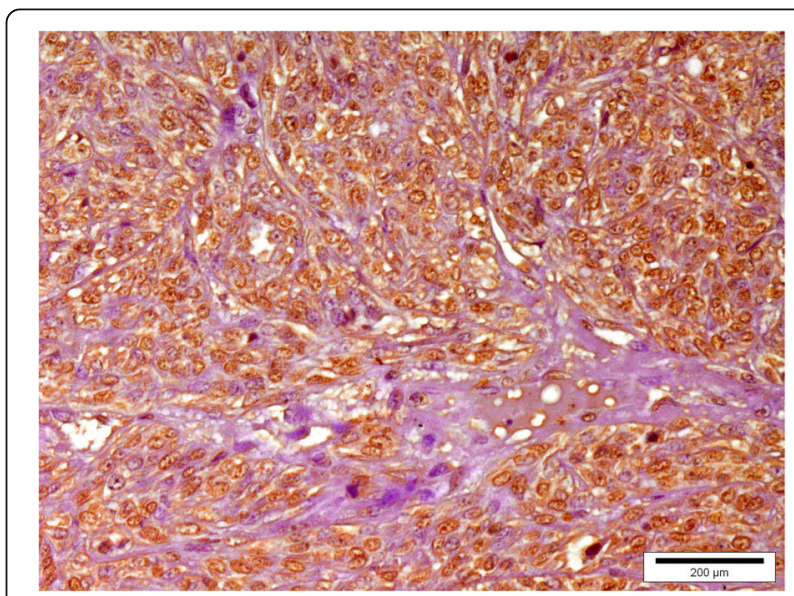

Fig. 7 Immunohistochemistry of canine mammary tumor (Fibrosarcoma showing mammaglobin-B immunopositive cells. $\mathrm{Bar}=200 \mu \mathrm{m}$ 


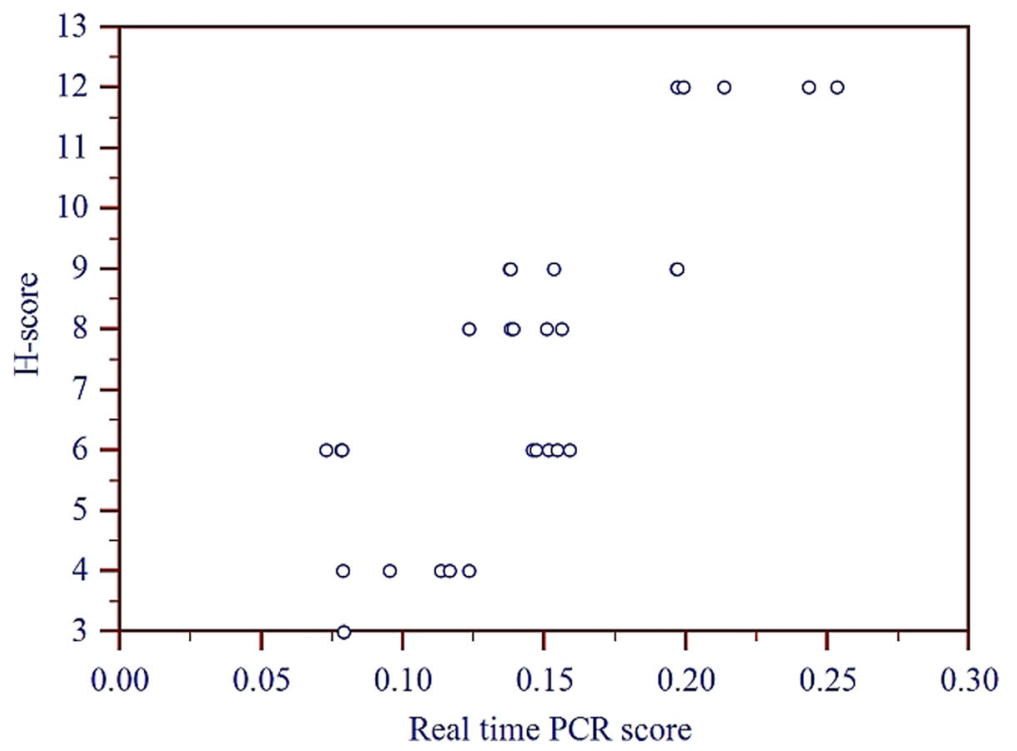

Fig. 8 Scatter plot showing positive correlation between mammaglobin-B transcript and protein expression

no information is available on its mRNA expression levels in CMT. So in this study, we evaluated the expression of mammaglobin-B mRNA in CMT by qRT-PCR. The gene was found to be significantly up-regulated $(6.663 \pm 0.841$ times) in CMT compared to the healthy glands. Our findings corroborate with the earlier studies carried out on human breast cancers which showed that mammaglobin transcript levels are higher by 10 folds in comparison to healthy breast tissue $[3,32]$.

Histopathology and IHC examination has been playing an important role as a diagnostic tool for neoplasms and pathogens [32, 33]. In human breast pathology, IHC is routinely used in the diagnosis and prognosis of breast neoplasia [34, 35]. In the present investigation, we found that majority of the examined CMT sections were carcinomas in nature, similar to the report of breast cancer [36]. According to Suchy et al., (2000) [37] the mammaglobin expression in breast tumors did not show any correlation with histological type, tumor grade, tumor stage or hormone receptor status. In corroboration with their findings, we also did not find any significant differences in terms of $\mathrm{H}$ score and qRT-PCR score with respect to CMT histotypes or their grades, suggesting that mammaglobin-B over-expression was irrespective of CMT histological types or grades. Overall, the protein was highly expressed in $76.7 \%$ of CMT tissues. However, in most of the healthy canine mammary tissues, a lower level of protein expression (SI score $<6$ ) was observed. Our findings are in accordance with the earlier reports, where a high frequency ( $80 \%)$ of mammaglobin protein expression was observed specifically in human breast cancer tissue $[38,39]$. In the present study, all the complex mammary carcinoma sections had higher mammaglobin- $\mathrm{B}$ expression as evidenced by their higher SI score. Whereas for simple carcinoma, mammaglobin-B expression was higher in $63.3 \%$ positive cases in the category. While, $50 \%$ each of carcinosarcoma and fibrosarcoma sections had high mammaglobin-B expression. The expression pattern of this protein in CMT types was different when compared to similar human breast cancer counterparts studied in the past $[40,41]$. The likely reason for this difference in expression may be the use of antibody specific to canine mammaglobin-B protein. Moreover, in the current study, no significant differences in terms of $\mathrm{H}$ score and qRT-PCR score with respect to CMT histotypes or tumor grades were observed which implies that, mammaglobin- $B$ is overexpressed irrespective of histological types or grades of CMT. So, this protein should be considered important while identifying any tumor of canine mammary gland origin using immunohistochemical staining.

\section{Conclusion}

Our study is the first ever attempt made to report overexpression of mammaglobin- $\mathrm{B}$ at mRNA and protein levels in CMTs. Here we also report a significant correlation between qRT-PCR and IHC scores for the diagnosis of mammary gland neoplasia in canines. Our results may provide the basis for developing a novel approach in veterinary diagnostic research, although additional studies using a large number of healthy and pathological clinical samples are required to validate these preliminary findings. Further, it would also be interesting to correlate the mammaglobin-B expression with other clinico-pathological parameters of CMT in future. As mammaglobin- $\mathrm{B}$ is highly expressed in $\mathrm{CMT}$ and to a 
low degree in healthy mammary tissues, it is capable of discriminating CMT subjects from healthy controls. Adding this protein to the current panel of diagnostic biomarkers will definitely improve the sensitivity and specificity of CMT diagnosis.

\section{Abbreviations}

CDNA: Complementary DNA; CMT: Canine mammary tumor; DAB: 3,3'Diaminobenzidine; HE stain: Haematoxylin and eosin stain; HRPO: Horse radish peroxidase; $I H C$ : Immunohistochemistry; NBF: Neutral buffered formalin; qRT-PCR: Quantitative real time polymerase chain reaction; RPS 19: Ribosomal protein S19; SAS: Statistical analysis software; $\beta$-actin: Beta actin

\section{Acknowledgements}

We are thankful to Dr. Priya K Gopal (Centre of Advanced Studies, Kolkata) for editing the language of the manuscript.

\section{Funding}

Department of Biotechnology, India vide grant no. BT/PR6434/GBD/27/414/2012 provided necessary funds to carry out the experiments. Apart from providing funds, DBT also provided critical suggestions regarding the technical programme of the project and approved it. Department of Science and Technology, India (DST; INSPIRE) provided Ph. D. Fellowship (DST/INSPIRE FELLOWSHIP/2013/145) to the first author.

\section{Availability of data and materials}

All data generated or analysed during this study are included in this manuscript. Sequence information of the gene (Mammaglobin-B) has been submitted to Genbank under accession number: AB971219.

\section{Authors' contributions}

MP performed the experiment, compiled results and wrote the manuscript. BVSK, the Principal Investigator of the project contributed in conception and design of experiment, analysis and interpretation of data, drafting and revision of the manuscript. KG carried out histopathological classification and grading of tumors, helped in performing $\mathrm{IHC}$. RSS helped in standardization of $\mathrm{IHC}$, semi-quantitative scoring of immunopositive cells, critically revised the manuscript. AK performed surgery of the animals, helped in collection of tissue samples and history of the animals, helped in drafting and revising the article. RV helped in designing the laboratory work, provided critical suggestions during experimentation, helped in critically revising the manuscript. All authors read and approved the final manuscript.

\section{Ethics approval and consent to participate}

Permission from the 'Institutional animal ethics committee' (IAEC) of Guru Angad Dev Veterinary and Animal Sciences University (GADVASU), Ludhiana, India, was required for collection of healthy and tumorous mammary tissues from dogs brought to the clinics of the university for surgical intervention. The same has been obtained vide Edrst no. VMC/12/3901-35 dated 06-08-2012 from IAEC, GADVASU.

A consent from the owners of the animals used in the study was also obtained prior to surgery.

\section{Competing interests}

The authors declare that they have no competing interests.

\section{Publisher's Note}

Springer Nature remains neutral with regard to jurisdictional claims in published maps and institutional affiliations.

\section{Author details}

'School of Animal Biotechnology, Guru Angad Dev Veterinary and Animal Sciences University, Ludhiana, Punjab 141004, India. ${ }^{2}$ Department of Veterinary Pathology, Guru Angad Dev Veterinary and Animal Sciences University, Ludhiana 141004, India. ${ }^{3}$ Department of Veterinary Surgery and Radiology, Guru Angad Dev Veterinary and Animal Sciences University, Ludhiana 141004, India.
Received: 15 January 2018 Accepted: 29 May 2018

Published online: 15 June 2018

\section{References}

1. Merlo DF, Rossi L, Pellegrino C, Ceppi M, Cardellino U, Capurro C, Ratto A, Sambucco PL, Sestito V, Tanara G, Bocchini V. Cancer incidence in pet dogs: findings of the animal tumor registry of genoa, Italy. J Vet Intern Med. 2008;22(4):976-84.

2. Klug J, Beier HM, Bernard A, Chilton BS, Fleming TP, Lehrer Rl, Miele L, Pattabiraman N, Singh G. Uteroglobin/Clara cell 10-kDa family of proteins: nomenclature committee report. Ann N Y Acad Sci. 2000;923:348-54.

3. Watson MA, Fleming TP. Mammaglobin, a mammary-specific member of the uteroglobin gene family, is overexpressed in human breast cancer. Cancer Res. 1996;56(4):860-5.

4. Zehentner BK, Carter D. Mammaglobin: a candidate diagnostic marker for breast cancer. ClinBiochem. 2004;37(4):249-57.

5. Colpitts TL, Billing-Medel P, Friedman P, Granados EN, Hayden M, Hodges S, Menhart N, Roberts L, Russell J, Stroupe SD. Mammaglobin is found in breast tissue as a complex with BU101. Biochemist. 2001;40(37):11048-59.

6. Watson MA, Dintzis S, Darrow CM, Voss LE, DiPersio J, Jensen R, Fleming TP. Mammaglobin expression in primary, metastatic. and occult breast cancer Cancer Res. 1999:59(13):3028-31.

7. Gaaib JN, AL-Faisal AHM, Tobal K, Al-Alwan N. Evaluation the diagnostic and prognostic value of human mammaglobin (mgb 1) gene expression in Iraqi breast cancer patients. Int J Adv Res. 2014;2(4):663-9.

8. Al-Joudi FS, Kaid FA, Ishak I, Mohamed N, Osman K, Alias IZ. Expression of human mammaglobin and clinicopathologic correlations in breast cancer: findings in Malaysia. Indian J PatholMicrobiol. 2011;54(2):284-9.

9. Raica M, Cimpean AM, Meche A, Alexa a, Suciu C, Muresan a. Analysis of the immunohistochemical expression of mammaglobin a in primary breast carcinoma and lymph node metastasis. Rom J MorpholEmbryol. 2009:50(3):341-7.

10. Fritzsche FR, Thomas A, Winzer KJ, Beyer B, Dankof A, Bellach J, Dahl E, Dietel M, Kristiansen G. Co-expression and prognostic value of gross cystic disease fluid protein 15 and mammaglobin in primary breast cancer. HistolHistopathol. 2007:22(11):1221-30.

11. Roncella S, Ferro P, Bacigalupo B, Dessanti P, Giannico A, Gorji N, Moroni M, Tozzini S, Pensa F, Gianquinto D, Fais F. Relationship between human mammaglobin mRNA expression in breast cancer tissue and clinicopathologic features of the tumors. J ExpClin Cancer Res. 2006:25(1):65-72.

12. Li C, Zhang T. Human mammaglobin: a specific marker for breast cancer prognosis. J BUON. 2016;21(1):35-41.

13. Brown NM, Stenzel TT, Friedman PN, Henslee J, Huper G, Marks JR. Evaluation of expression based markers for the detection of breast cancer cells. Breast Cancer Res Treat. 2006:97(1):41-7.

14. Pandey M, Sunil Kumar BV, Verma R. Mammaglobin as a diagnostic serum marker of complex canine mammary carcinomas. Res Vet Sci. 2015;103:187-92.

15. Chomczynski P, Sacchi N. Single-step method of RNA isolation by acid guanidinium thiocyanate-phenol-chloroform extraction. Anal Biochem. 1987;162(1):156-9.

16. Wang YS, Chi KH, Chu RM. Cytokine profiles of canine monocyte-derived dendritic cells as a function of lipopolysaccharide- or tumor necrosis factoralpha-induced maturation. Vet Immunollmmunopathol. 2007;118:186-98.

17. Timmermans-Sprang EPM, Gracanin A, Mol JA. High basal Wntsignaling is further induced by PI3K/mTor inhibition but sensitive to CSRC inhibition in mammary carcinoma cell lines with HER2/3 overexpression. BMC Cancer. 2015;15:545-56

18. Sunil Kumar BV, Bhardwaj R, Mahajan K, Kashyap N, Kumar A, Verma R. The overexpression of Hsp90B1 is associated with tumorigenesis of canine mammary glands. Mol Cell Biochem. 2018:440(1-2):23-31.

19. Abasht B, Kaiser MG, Van der Poel J, Lamont SJ. Genetic lines differ in tolllike receptor gene expression in spleens of chicks inoculated with Salmonella enterica serovar Enteritidis. Poult Sci. 2009;88(4):744-9.

20. Livak KJ, Schmittgen TD. Analysis of relative gene expression data using real time quantitative PCR and the 2- $\triangle \Delta C T$ method. Methods. 2001;25(4):402-8.

21. McNeill RE, Miller N, Kerin MJ. Evaluation and validation of candidate endogenous control genes for real-time quantitative PCR studies of breast cancer. BMC Mol Biol. 2007;8:107-19.

22. Misdorp W, Else RW, Hellmen E, Lipscomb TP. Histologic classification of mammary tumors of the dog and the cat. In: World Health Organization international histological classification of tumors of domestic animals. 2nd ed. Vol 7. Washington, DC: Armed Force Institute of Pathol; 1999. p. 11-27. 
23. Goldschmidt M, Pena L, Rasotto R, Zappulli V. Classification and grading of canine mammary tumors. Vet Pathol. 2011;48(1):117-31.

24. Zakharchenko O, Greenwood C, Alldridge L, Souchelnytskyi S. Optimized protocol for protein extraction from the breast tissue that is compatible with two-dimensional gel electrophoresis. Breast Cancer (Auckl). 2011;5:37-42.

25. Towbin U, Staehelin T, Gordon J. Electophoretic transfer of proteins from polyacrylamide gels to nitrocellulose sheets: procedure and some applications. ProcNatIAcad Sci. 1979;76:4350.

26. Sethi RS, Brar RS, Singh O, Singh B. Immunolocalization of pulmonary intravascular macrophages, TLR4, TLR9 and IL-8 in normal and Pasteurellamultocida-infected lungs of water buffalo (Bubalusbubalis). J Comp Pathol. 2011;144:135.

27. Hewitt SM, Baskin DG, Frevert CW, Stahl WL, Rosa-Molinar E. Controls for immunohistochemistry, the histochemical society's standards of practice for validation of immunohistochemical assays J Histochem Cytochem. 2014;62(10):693-7.

28. KSJr MC, Szabo E, Flowers JL, Cox EB, Leight GS, Miller L, Konrath J, Soper JT, Budwit DA, Creasman WT, Seigier IF, KS MC Sr. Use of a monoclonal antiestrogen receptor antibody in the immunohistochemical evaluation of human tumors. Cancer Res. 1986;46(8):4244s-8s,

29. Rizzardi AE, Johnson AT, Vogel RI, Pambuccian SE, Henriksen J, Skubitz APN, Metzger GJ, Schmechel SC. Quantitative comparison of immunohistochemical staining measured by digital image analysis versus pathologist visual scoring. DiagPathol. 2012;7:42-51.

30. Pandey M, Sunil Kumar BV, Singh S, Verma R. Development of recombinant matrixmetalloproteinase-3 based sandwich ELISA for sero-diagnosis of canine mammary carcinomas. J Immunoassay Immunochem. 2016; https://doi.org/10.1080/15321819.2016.1211145.

31. Zach O, Kasparu H, Krieger O, Hehenwarter W, Girschikofsky M, Lutz D. Detection of circulating mammary carcinoma cells in the peripheral blood of breast cancer patients via a nested reverse transcriptase polymerase chain reaction assay for mammaglobin mRNA. J ClinOncol. 1999;17(7):2015-9.

32. Min CJ, Tafra L, Verbanac KM. Identification of superior markers for polymerase chain reaction detection of breast cancer metastases in sentinel lymph nodes. Cancer Res. 1998;58(20):4581-4.

33. Pena L, Gama A, Goldschmidt MH, Abadie J, Benazzi C, Castagnaro M, Diez L, Gartner F, Hellmen E, Kiupel M, Millan Y, Miller MA, Nguyen F, Poli A, Sarli G, Zappulli V, Martin de lasMulas J. Canine mammary tumors: a review and consensus of standard guidelines on epithelial and myoepithelial phenotype markers, HER2, and hormone receptor assessment using immunohistochemistry. Vet Pathol. 2014;51(1):127-45.

34. Leong TY, Cooper K, Leong AS. Immunohistology — past, present, and future. AdvAnatPathol. 2010;17(6):404-18.

35. Payne SJ, Bowen RL, Jones JL. Predictive markers in breast cancer-the present. Histopathology. 2008;52(1):82-90

36. Wang Z, Spaulding B, Sienko A, Liang Y, Li H, Nielsen G, Gong GY, Ro JY. Mammaglobin, a valuable diagnostic marker for metastatic breast carcinoma. Int J ClinExpPathol. 2009:2(4):384

37. Suchy B, Austrup F, Driesel G, Eder C, Kusiak I, Uciechowski P, Grill HJ, Giesing M. Detection of mammaglobin expressing cells in blood of breast cancer patients. Cancer Lett. 2000;158(2):171-8.

38. Bernstein JL, Godbold JH, Raptis G, Watson MA, Levinson B, Aaronson SA, Fleming TP. Identification of mammaglobin as a novel serum marker for breast cancer. Clin Cancer Res. 2005;11(18):6528-35.

39. Fanger GR, Houghton RL, Retter MW, Hendrickson RC, Babcook J, Dillon DC, Durham MD, Reynolds LD, Johnson JC, Carter D, Fleming TP. Detection of mammaglobin in the sera of patients with breast cancer. Tumor Biol. 2002;23:212-21

40. Bhargava R, Beriwal S, Dabbs DJ. Mammaglobin vs GCDFP-15: an immunohistologic validation survey for sensitivity and specificity. Am J ClinPathol. 2007:127(1):103-13.

41. Han JH, Kang Y, Shin HC, Kim HS, Kang YM, Kim YB, Oh SY. Mammaglobin expression in lymph nodes is an important marker of metastatic breast carcinoma. Arch Pathol Lab Med. 2003;127(10):1330-4.

\section{Ready to submit your research? Choose BMC and benefit from:}

- fast, convenient online submission

- thorough peer review by experienced researchers in your field

- rapid publication on acceptance

- support for research data, including large and complex data types

- gold Open Access which fosters wider collaboration and increased citations

- maximum visibility for your research: over $100 \mathrm{M}$ website views per year

At BMC, research is always in progress.

Learn more biomedcentral.com/submissions 